https://helda.helsinki.fi

\title{
Natural Equality and Natural Law in Locke's Two Treatises
}

\section{Saastamoinen, Kari}

Edinburgh University Press

2019-02

Saastamoinen, K 2019 , Natural Equality and Natural Law in Locke's Two Treatises . in I Hunter \& R Whatmore (eds), Philosophy, Rights and Natural Law : Essays in Honour of Knud Haakonssen . Edinburgh University Press , Edinburgh , pp. 127-146.

http://hdl.handle.net/10138/339515

unspecified

acceptedVersion

Downloaded from Helda, University of Helsinki institutional repository.

This is an electronic reprint of the original article.

This reprint may differ from the original in pagination and typographic detail.

Please cite the original version. 
This is a final draft of an article published in Philosophy, Rights and Natural Law: Essays in Honour of Knud Haakonssen, ed. Ian Hunter and Richard Whatmore, Edinburgh University Press 2019.

\section{Natural Equality and Natural Law in Lodke's Two Treatises}

Kari Saastamoinen

The idea that human beings are equal by nature is a standard topic in modern commentaries on John Locke's political theory.1 Together with its sister concept natural liberty it is often associated with the idea of Locke as an early representative of liberal political thought. Locke's notions of natural liberty and equality are seen as signs of his commitment to the values of individual autonomy and political equality held central in liberal-democratic societies of today, and his political theory is read as a more or less successful attempt to articulate those values. In this chapter, I will argue that such an approach to Locke's remarks on natural equality is historically misleading, and they are best understood when we take seriously the fact that he developed his political theory within the parameters of seventeenth-century natural law.2

In recent years the most sophisticated and widely discussed proto-liberal interpretation of Locke's natural equality has been the one proposed by Jeremy Waldron in his monograph God, Locke, and Equality.3 Commentators have paid much attention to Waldron's views concerning the role of Christian religion in Locke's political theory, and to his attempt to square Locke's remarks on human species in Two Treatises with the critique of the traditional notion of the species presented in An Essay concerning Human Understanding.4 What has received less critical attention is Waldron's claim that behind Locke's political theory was a doctrine of 'basic equality'. By basic equality Waldron means that fundamental but abstract commitment to human equality which lies behind all respectable political theories of today, and which enables us to analyze these theories as rival accounts of what it means to treat human beings as equals. 5 Waldron holds that, while Locke's political theory commented on issues which were relevant in late seventeenth-century England, behind those comments was a commitment to basic human equality similar to the one we find in modern moral and political thought. 6 In God, Locke, and Equality Waldron, following Ronald Dworkin's formula of fundamental equality, characterizes this basic equality as equal respect and concern.7 However, in the essay 'Basic Equality', written a few years later, Waldron is more cautious, holding now that in Locke's case we shouldn't speak about equal concern, at least in any 
active sense of the term. 8 This leaves us with equal respect. While this is an idea with obvious Kantian overtones, what Waldron finds in Locke is not the Kantian Achtung we owe to all rational beings as ends in themselves, but the idea that we owe equal respect to all human beings as creatures who are able to know God and his law, and to whom God has offered the possibility of life after death. 9

If we are purposefully reading Locke as an early liberal, equating natural equality with equal respect easily appears as a fruitful way of analysing his political theory. Given the role the idea of respecting humanity plays in much of modern moral and political thought, this approach seems to make Locke's theory highly relevant to our present concerns. If, however, we are interested in understanding Locke's theory historically, things become more complicated. After all, Locke never explicitly mentioned the idea that we owe equal respect to human beings due to their status as God's special creatures, nor did he use the term 'respect' when discussing the natural equality of human beings.10 This leaves the possibility that equal respect operated as an unpronounced background assumption in Locke's theory. But as Waldron points out, such an idea is difficult to combine with Locke's expressed opinions on issues such as the subordinated position of women in marriage, the bestialisation of criminals, and the class structure of the English constitution.11 It is equally tricky to see how such an abstract idea of equal respect fits with the fact that Locke explicitly affirmed the existence of non-consensual relations of authority and subjection among human beings, remarking that things such as birth, alliance and benefits can subject a person 'to pay an Observance to those to whom Nature, Gratitude or other Respects may have made it due'.12

In what follows I will argue that the relationship between Locke's notion of natural equality and the above elements in Two Treatises is best understood if we abandon the Kantinspired idea of equal respect and pay attention to how natural equality was conceived in seventeenth-century political thought. In this respect, the crucial observation is that the idea of human beings as free and equal by nature was widely shared in early modern Europe, and that these notions usually referred to the idea that natural law gives no individual political power over another. In Two Treatises Locke followed this traditional practice, using the notion of natural equality to denote his own particular version of the view that no person has inherent political authority over another. To be sure, the version he offered was in some respects novel and unconventional. Yet it did not include or presuppose anything like the idea of equal respect. As has been noted in previous historically oriented scholarship, the natural equality Locke defended was noticeably jural in character.13 Behind such an account of equality was the idea that, while there are non-consensual 
moral hierarchies among human beings, due to their personal obligation to preserve their own lives, they are all on the same moral footing with respect to issues relevant to life and death.

The notions of natural equality and natural liberty (the two concepts were often seen as interchangeable) were no novelties when Locke wrote Two Treatises. They had been articulated already in antiquity, the locus classicus being Corpus iuris civilis, in which Ulpian maintained that according to natural law human beings are free and equal, wherefore slavery is against natural law (though approved by the law of nations).14 These notions were adapted to the Christian tradition, used in scholastic philosophy, and often mentioned in early modern political thought.15 The natural liberty and equality of human beings was affirmed, for example, by a line of sixteenth- and seventeenth-century Jesuits, including widely read authors such as Luis de Molina, Robert Bellarmine and Francisco Suarez. While the character of natural equality and liberty varied from author to author, and these concepts were used for multiple purposes, they referred predominantly to the idea that no individual is by nature a servant of another. This was usually not understood to mean that the origin of political power would be in the consent given by individuals, as individual human beings were not seen as possessing rights which could be used as building blocks for political authority. M ost often political power was understood to be established by the people as an already existing corporate entity, though Suarez brought up the idea of an agreement between male householders. 16

Until the first half of the seventeenth century, natural equality and liberty were most often seen as notions which help us to understand the proper character of human power relations, and were not conceived as subversive with respect of prevailing social hierarchies. During the English Civil War Leveller pamphleteers such as Richard Overton and John Lilburne used Roman law and Christian formulations of natural liberty and equality to argue that English freemen were politically equal.17 At the same time a new way of understanding natural equality was introduced by Thomas Hobbes, partly perhaps as a reaction to the radicalism expressed in Leveller pamphlets.18 Hobbes associated notions of natural liberty and equality vividly with the idea that the state is a human artefact which comes into being by a contract between free and equal individuals. To be sure, the equality he attributed to individuals living in the state of nature lacked traditional references to natural law, consisting mainly in their shared capacity to kill each other. However, Hobbes also referred to natural equality when discussing the laws of nature, i.e. the rules of reason needed to achieve peace. Here, he pointed out that irrespective of the possible differences in individual human abilities, all human beings have a strong tendency to regard themselves as equal 
with others and are not inclined to join a commonwealth unless this happens on equal terms. From this followed a principle of natural law: 'That every man acknowledge other for his Equall by Nature.' Such recognition meant above all that people do not demand for themselves rights which they are not to ready grant others, admitting that civil hierarchies are established by the sovereign.19

The idea that maintaining peace requires us to recognise others as our equals by nature was adopted by the most widely read natural law theorist of the period, Samuel Pufendorf. In his main work on natural law, De jure naturae et gentium (1672), Pufendorf defined natural law as a God-imposed rule which is known by natural reason, and which obligates human beings already in the state of nature irrespective of their religious confession. Offering a demonstrative account of natural law, Pufendorf first established that in order to survive and develop the special abilities God has given them, human beings need social life and interaction. For this purpose, they need to act towards each other in a manner which pacifies as much as possible their inherent tendency to aggressive behaviour. Thus, the fundamental principle of natural law is the duty to maintain and promote peaceful sociality (socialitas) among human beings. Other precepts of natural law are then demonstrated by showing that they are, given human nature and condition, necessary means for maintaining sociality. A significant observation in this regard is that while individuals vary greatly in their ability to govern their own actions, they are all highly concerned about their status as human beings. As a result, they are incapable of maintaining peaceful relations with persons who claim for themselves a higher ranking as human beings. Since natural law requires us to maintain peaceful sociality with all human beings, everyone 'must esteem and treat other men as his natural equals, or men in the same sense as he'.20 This happens, above all, by recognising that relations of domination and servitude are never established by nature alone, but always include an element of consent.21

Locke was aware of the popularity of natural equality already when he wrote the essay nowadays called 'Second Tract on Government' (c. 1662). There, he explained how authors discussing the origins of civil power can be divided into two rival camps. One group claims that the origin of government is to be found in paternal right, indicating that 'men are born in servitude'. Others take as their starting point 'an equality between men founded on the law of nature', holding that human beings are born 'to liberty'. In this early writing Locke saw no need to take sides. Yet he commented on the latter position by pointing out that a commonwealth always requires a sovereign who is not accountable to any earthly power, and that 'such power can never be established unless each and every individual surrenders the whole of this natural liberty of his, however great it may 
be, to the legislator'.22 In 'An Essay on Toleration' from 1667 Locke had already changed his mind, despite his formal neutrality between the idea that 'monarchy is jure divino' and the contractual theory. Now, he ridiculed the first mentioned doctrine, and explained that if political authority is derived 'from the grant and consent of the people', it cannot be assumed that people would give anyone such power 'for any other purpose than their own preservation'.23 Yet, Locke did not explicitly mention natural equality in this context, and it was only when he needed to confront Robert Filmer in Two Treatises that he discussed this topic in any detail.

We know that when Locke was writing Two Treatises he was familiar with Pufendorf's De jure, and later he expressed his admiration for the book.24 Yet, while Locke was evidently inspired by several elements in Pufendorf's theory, 25 their accounts of natural law differed in some respects significantly. Above all, Locke did not adopt Pufendorf's pivotal idea of promoting sociality as the fundamental principle of natural law, but gave this status to our duty to preserve our own lives and, when these are secure, the life of others.26 The main purpose of Pufendorf's doctrine of socialitas, including the duty to recognise natural equality, was to make apparent how all social hierarchies and institutions are founded on human contracts and imposition, and to eliminate moral and religious pretexts for civil strife.27 In Two Treatises, on the other hand, the fundamental principle of natural law offered citizens a moral criterion for evaluating the legitimacy of political authority and a justification for overthrowing a ruler who had lost their trust. Before exploring how such understanding of natural law was connected to natural equality, we should look at the peculiar idea of natural inequality Locke aimed to refute in Two Treatises.

I $\quad t$ is well established that Locke's main intellectual adversary in both Treatises was Robert Filmer, whose works had been republished (or in the case of Patriarcha published for the first time) during the Exclusion crises. In Patriarcha Filmer had observed that the idea of human beings as free and equal by nature was widely shared 'by divines as by divers other learned men', referring especially to Bellarmine and Suarez, but also mentioning 'over 186 
zelous' Calvinists such as George Buchanan. Filmer claimed that these authors had used notions of natural liberty and equality to justify the view that the people have a right to choose any form of government they please and even a right to punish the king, if he violates the laws of the monarchy. 28 In doing so they had failed to notice that if all human beings truly are free and equal by nature, this means that every individual, not only the organised elite traditionally associated with the term 'the people', is entitled to govern his or her actions independently of others. And Filmer was quick to point out the difficulties involved in any attempt to derive the form of government from the decision of the multitude.29 The idea of natural inequality Filmer vigorously defended in his works was not the Aristotelian one, in which all relations of domination and servitude in civil life reflect differences in individual virtues and abilities. Instead of the multi-layered natural social hierarchy following from the Aristotelian position, Filmer postulated one grand inequality founded on birth which prevailed between the monarch and his subjects. The power of each king had its origin in the patriarchal power God had given to Adam over his offspring and the whole world. It consisted of the absolute and arbitrary domination over the life, death and material possessions of all his subjects, giving the monarch a full right 'to preserve and to distribute to every subordinate and inferior father, and to their children, their rights and privileges'. 30

It was this grand inequality with respect of life and death which Locke confronted with his account of natural equality. In order to argue that legitimate political power, i.e. the 'Right of making Laws with Penalties of Death, and consequently all less Penalties',31 can only be founded on consent and trust, and can never be absolute and arbitrary in character, Locke needed to refute Filmer's claim about the huge innate disparity between the monarch and his subjects. In order to do so, it was not necessary for him to attribute all sorts of equality to human beings. All Locke needed to show was that they are equal in the sense that no one has by nature political power over others. This is, I will argue, all he did, and he did it by claiming that due to their shared God-imposed duty to follow the law of preservation, human beings are all on the same moral footing with respect of life and death. Of course, this alone was not enough to prove that absolute political power could not be established by consent. This element in Locke's argument did not rely on his notion of natural equality, but on the claim that the law of preservation makes any attempt to establish absolute political authority by contractual means morally invalid. 32

To be sure, Locke also maintained, pace Filmer, that the duty of each individual to preserve his or her life gives everyone in the state of nature an equal right to use other creatures for maintaining and improving their lives, and a right to own property. And in the first Treatise he 
associated natural equality with the idea that 'everyone ought to partake in same common Rights and Privileges'. It should be noted, however, that Locke presented this characterisation of natural equality in the middle of his argument for the view that a ' $M$ an has a Natural Freedom' in the sense that only 'a M an's own consent subjects him to a Superior'. 33 While we may well say that in Locke's theory human beings are equal with respect of natural rights, his explicit arguments for natural equality were targeted at showing that no one has by nature political power over others.

Before exploring Locke's arguments in more detail it should be noted that his muchcited chapter on the state of nature in the second Treatise includes formulations which, if read in isolation, appear to indicate that the scope of natural equality is broader than the mere absence of political power relations. First of all, Locke declares that this state is a condition of 'perfect Freedom' in the sense that everyone has the liberty 'to order their Actions, dispose of their Possessions and Persons as they think fit, within the bounds of the Law of Nature, without asking leave or depending upon the will of any other Man'.34 A little later he adds that in the state of nature everybody has, in relation to other human beings, 'an uncontroleable Liberty, to dispose of his Person and Possessions'.35 By strongly emphasising personal autonomy in the state of nature these remarks give the impression that natural liberty and equality rule out not only political power relations but every form of authority one person has over another. Such an interpretation seems to find further confirmation when Locke remarks that the state of nature is a condition of equality in the sense that not only all 'Jurisdiction' but also 'all the Power' is reciprocal, 'no one having more than another'.36 In the previous chapter Locke has distinguished political power from the power husbands have over their wives and masters over their servants, making it clear that only the first mentioned includes the juridical right of imposing laws sanctioned by punishments.37 When Locke now says that in the state of nature 'all power' is reciprocal, this could be understood to mean that every sort of authority, not only political power, needs to be founded on consent, especially as he a little later characterises the state of nature as a condition of 'perfect Equality'.38

If the above expressed Locke's considered view on the issue, natural equality could not be a moral precept interlocked with the fundamental principle of preservation, but would need an independent moral foundation, such as equal respect. But as is well known, at the beginning of the chapter on paternal power Locke explicitly remarks that when in the chapter on the state of nature he declared that 'all Men are by Nature Equal', he did not mean 'all sorts of Equality', specifying that 'the Equality I there spoke of, as proper to the Business in Hand', was equality 'in respect of Jurisdiction or Domination one over 189 

another'. 39 It is significant to note that this is not a reassessment Locke makes after realising that he may have been too egalitarian in the chapter on the state of nature. Already that chapter includes passages which strongly suggest that remarks indicating total personal autonomy should be seen as overstatements, motivated perhaps by a wish to repudiate Filmer's grand natural inequality with an equally bold declaration of natural liberty and equality. The most obvious example is the observation that human beings remain in the state of nature until they 'by their own Consent make themselves M embers of some Politic Society; other Promises and Compacts, Men may make one with another, and yet still be in the State of Nature'.40 As households precede civil society both theoretically and historically, this statement indicates that the domestic subjection of wives and servants does not remove them from the condition of liberty and equality, a positon which makes perfect sense if liberty and equality refer here to the absence of political power.

The jural character of natural equality is also implied in the much-cited remark that 'there is nothing more evident than that Creatures of the same species and rank, born to the same advantages of Nature, and the use of same faculties, are equal amongst another without Subordination or Subjection'.41 After the publication of Waldron's God, Locke, and Equality, it has been popular to ponder how this passage should be understood in the light of what Locke says in An Essay concerning Understanding about the idea of the species, and about the human capacity to make abstractions and to have the idea God. 42 Recently, Timothy Stanton has pointed out that we should be careful when using philosophical ideas formulated in the Essay to explicate Locke's views in Two Treatises. In the Essay Locke uses terms such as 'man' and 'person' to denote well-defined ideas which abstract clear-cut features from our sensory ideas, whereas in Two Treatise he is relying on what he in the Essay calls the 'civil Use' of words.43 This consists of terms which get their meaning in everyday conversation and represent ideas which are less precise than the ones used in the Essay. While the use of well-defined ideas is necessary for the philosophical purposes of the Essay, the civil use of words is better suited for 'the upholding of common Conversation and Commerce, about the ordinary Affairs and Conveniences of civil life, in the societies of men, one amongst another'.44 They definitely offer appropriate vocabulary for a work which aims at convincing a larger group of readers, many of them unfamiliar with the Essay, of the legitimacy of overthrowing a monarch. Therefore, in Two Treatises Locke does not hesitate to speak about the human species and to use the term 'man' in the everyday sense of 'a thinking or rational Being' which has 'a Body so an so shaped joined to it'.45 
I find Stanton's observation about Locke's civil use of words extremely valuable in this context. Yet, I do not entirely agree with his suggestion that in the case of natural equality Locke still relies on the philosophical idea of a human being as a creature subject to law. Stanton refers here to Locke's remark that 'God having given $M$ an an Understanding to direct his Actions, has allowed him freedom of the Will, and liberty of Acting ... within the bounds of that Law he is under.' 46 From this, Stanton concludes that when Locke speaks about human beings belonging to the same species and being born to the use of the same faculties, this means nothing more than that they are 'equally capable of grasping and following' the law God has imposed on them. 47 If taken literally, this would mean that it is the mere ability to know and observe God's law, irrespective of the content of this law, which makes human beings equal by nature. Such a proto-Kantian interpretation would make it problematic to claim that Locke's natural equality only refers to the absence of political power in the state of nature, but it would also leave us wondering why Locke bothers to point out that human beings are 'born to the same advantages of Nature'. In my view, we can make better sense of Locke's various remarks on this issue once we notice that they rely not only on the human capability of knowing and observing natural law. What is equally important is the central content of this law, the duty of each individual to preserve his or her life.

It may be tempting to assume that since God has raised human beings above other creatures by endowing them with intellectual and moral abilities, it follows that God also wants them to preserve their lives. Yet scholars have had difficulties in finding justifications for the duty of self-preservation or the immorality of suicide in the Essay, where Locke analyses moral agency in terms of well-defined ideas. 48 of course, Locke famously explains how any corporeal creature with an ability 'to understand general Signs, and to deduce Consequences about general Ideas' should be regarded as a ' $M$ an' in the moral sense of being a creature 'subject to Law'. 49 But the fact that a creature is subjected to law does not give us the content of this law. Moreover, even if we understand that the law God has imposed on us aims to promote our happiness, how do we know for sure that it forbids us to terminate our earthly existence? In the essay 'M orality' (1677-8) Locke remarks 'that man is capable of some degrees of happiness and great degrees of misery in this life', adding that it is 'possible that there may be a state after this life wherein men may be capable of enjoyments or suffering'.50 If our rational faculties give us such a gloomy picture of our worldly existence, why should we conclude that we have a duty to preserve our lives?

In Two Treatises this question is answered when Locke in the first Treatise explains how we know that God has given every individual a right to use other creatures for preserving and 
improving their lives. Locke points out that, while God has endowed human beings with special intellectual and moral abilities, he has also planted in them, 'as in all other Animals, a strong desire of Self-preservation, and furnished the World with things fit for Food and Rayment, and other Necessaries of Life'. It is only when we pay attention to all these aspects of God's creation that we become aware of God's 'design, that M an should live and abide for some time upon the Face of the Earth, and not that so curious and wonderful a piece of Workmanship, by his own Negligence, or want of Necessaries, should perish again, presently after a few moments continuance'. A person reflecting on all these things understands that the 'strong desire of Preserving his Life and Being' has been 'Planted in him, as a Principle of Action by God himself'. Therefore, his reason cannot but 'assure him' that by following this natural inclination he obeys 'the will of his Maker'.51

In the second Treatise Locke explains that since small children are incapable of knowing and observing the law of preservation, they must live under the quasi-juridical authority of their parents. It is important to note that it is not the lack of reason alone which submits children to the authority of their parents. The crucial thing is that due to their inadequate rational abilities children are incapable of preserving themselves. If God had made the world such an amicable place in which children could survive and develop without any help and instruction from an adult, their lack of reason would not give parents similar authority over them. Parental power is needed because the world into which a child is born is place in which the 'Necessities of his Life, the Health of his Body, and the Information of his M ind ... require him to be directed by the Will of others and not his own'.52 Accordingly, children emancipate from parental authority when their rational abilities make them capable of knowing the law of preservation and observing it of their own accord. When Locke declares that 'God having given M an an Understanding to direct his Actions, has allowed him freedom of the Will, and liberty of Acting ... within the bounds of that Law he is under',53 he is not speaking about law as an abstract idea, but is referring to the law of preservation. The freedom 'of $M$ an and Liberty of acting according to his own Will' is not founded on rational abilities as such. It 'is grounded on his having Reason, which is able to instruct him in that Law he is to govern himself by', i.e. the law of preservation.54 The fact that all normal adults are capable of and entitled to observe this law independently of others means, first and foremost, that they are personally accountable to God for preserving their own lives.

In the chapter on the state of nature Locke takes the above observations as given. When he says that human beings are 'Creatures of the same species and rank', he points out that while they share with other animals a strong desire for self-preservation, they are also endowed 
with intellectual and moral abilities which raise them above other earthly creatures. By noting that human beings are 'promiscuously born to all the same advantages of Nature', Locke reminds his readers of the fact that God has furnished the world with creatures which they can use to maintain their lives and that everyone is by nature entitled to do so. By adding that human beings are born to the use of 'the same faculties', he emphasises that every adult has an ability to know and a right to observe natural law of their own accord. Together all these observations indicate that every human being is personally accountable to God for preserving his or her life. Therefore, no one is obliged to obey another person in matters important for preservation, and no one is entitled to impose his or her will on others by using the threat of punishment.

It might be protested that the above makes Locke's argument overdetermined, that the conclusion is too obviously implied in the premises. But this is exactly the point. Locke is not making an overstatement but merely stating the obvious when he declares that 'there is nothing more evident' than that creatures with the above natural and moral characteristics are equal in the sense of being 'without Subordination or Subjection'. That the absence of natural subjection refers here solely to political power finds further confirmation in Locke's remark that relations of authority in the state of nature would be different only if it could be shown that God has given some individual 'an undoubted Right to Domination and Sovereignty'.55 Nothing less than such a God-given power over life and death could alter the character of the state of nature.

When Locke in paragraph II.6 explains why the state of nature is not a state of license, he re-states that it is governed by natural law, adding now that 'Reason, which is that Law, teaches all Mankind, who will but consult it, that being all equal and independent, no one ought to harm another in his Life, Health, Liberty, or Possessions'.56 By this Locke is not saying that the duty to abstain from harming others would be founded on natural liberty and equality. His idea is that the same principles which make human beings free and equal in the state of nature also impose moral restrictions on their behaviour in that state. The rest of the paragraph consists of three different formulations of this one idea. The first is the much-cited remark that we are all God's property and servants, 'sent into the World by his order, and about his business'. In the first Treatise Locke has made it clear that the most elementary worldly business for which God has sent human beings into the world is the preservation of their own lives. Here, he points out how this fact imposes moral norms on how we should behave towards others, as God wants everyone 'to last during his, not one another's Pleasure'. Accordingly, while the fact that we are creatures who share 'one Community of Nature' and are 'furnished with like Faculties' makes it evident that we are equal in the sense that 
there is no natural political power among us, these features also indicate 'that there cannot be supposed any such Subordination among us, that may Authorize us to destroy one another'. Finally, just as we know that God has imposed on us a duty of self-preservation, so 'by the like reason' we can conclude that God has done so to every human individual. Thus, when a person's 'own Preservation comes not in competition, ought he as much as he can, to preserve the rest of M ankind'. This means that we should abstain not only from killing other human beings but also from harming things which advance their preservation, including their liberty in the sense of freedom from arbitrary coercion, which Locke characterises as 'the Fence' to their preservation. 57

The above makes it easier to understand Locke's infamous statement that a person who violates central precepts of natural law can be 'destroyed as a Lyon or a Tyger'.58 Timothy Stanton has suggested that Locke is here relying on the functional moral idea of humanity or 'man', defined in the Essay as a creature who not only knows a law but also observes it.59 This assessment should, however, be specified by the observation that the law in question is the law of preservation. Murderers are to be 'treated as Beasts of Prey' not simply because they disobey God's law, but because the law they violate is the one God 'has set to the actions of Men, for their mutual security'.60 By violating the law of preservation murderers abandon the rule which makes the humankind 'one Community' and 'one Society distinct from all other Creatures'.61 It may not be self-evident that all this necessitates the conclusion that we should treat those who violate the law of preservation like people in the seventeenth century treated wolves, lions and tigers. Locke's choice of words may be motivated not only by a wish to demonise rulers with absolutists aspirations, but also by an awareness of the fact that when he argues for a natural right to execute natural law, he is offering every individual a right which is traditionally seen as belonging solely to God.62 The important thing in this context is that once some people leave the human community founded on the law of preservation, Locke's notion of natural equality includes no deeper idea of respect which could still constitute a moral tie between them and us.

In Locke's theory, human beings are equal by nature because they are all personally accountable to God for preserving their own lives, wherefore no one has by nature a right to impose on others laws sanctioned by punishments. Such equality does not preclude the existence of nonconsensual forms of authority which are not concerned with issues vital for life and death and do not include a right to punish. In such moral relationship I have a duty to obey the wishes of another, or at least to take them very seriously, but the other person is not entitled to punish me, if I fail to fulfil his or her request. The existence of such moral forms of authority and obedience is explicitly 
affirmed when Locke in paragraph II.54 remarks that by natural equality he does not mean 'all sorts of Equality'. He clarifies this point by making a distinction between two ways in which human beings are subjected to another person. They may be under the 'Jurisdiction or Domination' of another, or they are subjected 'to pay an Observance' to someone else. The latter form of authority does not require the consent of the subjected party, as Locke points out how 'Birth may subject some, and Alliance or Benefits others, to pay an Observance to those to whom Nature, Gratitude, or other Respects, may have made it due'.63

In Two Treatises Locke is interested in the origin and character of political power and has no reason to say much about moral forms of authority and subjection. But as we shall see below, the work includes at least three short references to such moral relations. They all seem to be founded on natural law, and might perhaps be understood in terms of imperfect rights and duties Locke presumably knew from Pufendorf's De jure.64 Yet, in one of the three instances, Locke's remarks seem to imply that moral authority can be strengthened by civil laws, which is against the idea of imperfect rights and duties as explained by Pufendorf.65 In any case, Locke's decision not to bother his readers 'with the particulars of the Law of Nature' makes it difficult to be more specific on this issue.66 From what he says about the law of opinion in the Essay we can gather that such moral relations of authority can be powerfully sanctioned by the social pressure established by other people's approval and condemnation. In fact, Locke holds that for most people these sanctions offer a stronger motive for obedience than the sanctions associated with civil law or divine law.67

John Marshall has suggested that when Locke refers to moral authority founded on 'Alliance or Benefits' he is supporting one of the central elements of social cooperation in late seventeenth-century England, namely that of giving favours and subjecting others through gratitude. This was a practice so familiar to the social classes Locke had in mind 'that it simply did not need to be expressed at any length in the Treatise'.68 Such practice seems to be assumed when Locke remarks that a person may owe 'gratitude to a Benefactor, to such a degree, that all he has, all he can do, cannot sufficiently pay it'.69 When he continues by emphasising that even in such extreme cases the benefactor has no right to impose laws on the person who owes him or her gratitude, the observation gets it's meaning from the idea that duties associated with gratitude are powerful and may include an obligation to take the wishes of the benefactor extremely seriously. In a culture where moral norms related to favours, gifts and gratitude are less demanding and not sanctioned by strong social pressure, such a comparison between duties of gratitude and political power hardly makes any sense. 
That gratitude is a part of natural law can be gathered from Locke's remark that the honour matured children owe to their parents follows from gratitude and is imposed by 'the Law of God and Nature'.70 M oral authority founded on gratitude is explicitly mentioned when Locke points out that the honour grown-up children owe to their parents includes not only respect, reverence and support, but 'compliance too'.71 The same idea is implied in the remark that in the case of adult children the 'Duty which is comprehended in the word honour, requires less Obedience' than in the case of small kids, but for the grown-ups 'the obligation is stronger'.72 Nothing here gives us a reason to conclude that less obedience would mean no obedience at all. While parents have no juridical or quasi-juridical authority over their full-grown offspring, they are not without moral authority on issues not directly related to life and death, such as who to marry or what profession to choose. Thus, Locke does not contradict his account of natural equality when in A Letter concerning Toleration he points out how no one complains if their neighbours manage their private domestic affairs badly, offering as an example the observation that no 'man is angry with another for an Error committed in sowing his Land, or in marrying his Daughter'.73 That parents use moral authority over their offspring in marital issues is fully in accordance with the juridical equality which prevails between them, provided parents remember that they are not entitled to punish their adult sons and daughters if they refuse to obey their wishes. 74

The best-known example of moral authority and subjection in Two Treatises is Locke's claim that marital relationship needs one head, and that it is the husband as 'the abler and the stronger' of the spouses who should enjoy the dominant position. In so far as Locke is here analysing marriage in the state of nature, he is not contradicting his account of natural equality. As is well known, Locke carefully explains that the authority the husband has over his wife is restricted to issues important for the purpose of their union. It includes no political or juridical authority over the wife, and gives 'the Husband no more power over her Life, than she has over his'.75 Things become more complicated when Locke in the first Treatise tells us that this arrangement is generally ordered not only by 'customs of Nations' but also by 'the Laws of Mankind'. 76 Of course, Locke could argue that in political societies wives have given their consent to civil authority, and that it serves the common good to strengthen the authority of the husband by civil laws. Yet it is difficult to see how such legislation would be compatible with Locke's statement that civil laws should be the same for everyone.77 At this point Locke seems to depart from the idea that all human beings, men and women alike, are on a similar moral footing in respect of issues relevant to life and death. It is important to bear in mind, though, that with his remarks on marriage Locke is not defending the 
women of his time from domestic abuse, but refuting Filmer's claim that the marital relationship gives the husband political authority over his wife.78

The ambivalence in Locke's remarks on marital authority appears to be connected to the exclusion of women from political rights. On this issue, Locke accepts the mainstream prejudices and social conventions of his time. Yet, it should be noted that in Two Treatises the precise form of government and the extent of political representation are largely questions of expediency and convention. Nothing in the natural equality of human beings makes one form of government inferior to another, save absolutism, which is incompatible with natural law. In the early innocent days of humankind pure monarchy was a perfectly suitable form of government for people connected by kinship ties. After the invention of money, kings became vain and greedy and the people found 'their Properties not secure under the government' of one man. As a result, 'the Legislature was placed in collective Bodies of men, call them Senate, Parliament, or what you please'.79 The reason for establishing such institutions was not a wish to make the government more democratic, but the idea that they would make it easier for the citizens to control those using political power. The maledominated English constitution, with its House of Lords and forty-shilling freeholders, is not demanded by natural equality, but nor does it contradict this principle. What is important is that the government does its job in protecting life, liberty, limbs and possessions. The one feature in Locke's doctrine of well-ordered political community which may be seen as partly dictated by his account of natural equality is the view that civil laws should be the same for everyone (though Locke fails to explain how this applies to women).80 The reason for this is not that civil laws should reflect equality as a political value. It is rather their aim to advance the common good and the fact that due to the character of their ultimate sanction, all civil laws are 'laws of Life and Death'.81

Above I have argued that there is no conception of basic equality to be found behind Locke's remarks on natural equality. In Two Treatises natural equality was not an independent moral principle with a philosophical foundation of its own. Nor was it understood as a value which should be actualised in political society as much as possible. Natural equality was a label Locke used to denote the moral fact that no one has by nature political power over others, and, more generally, that everyone is on the same footing with respect to things relevant to life and death. There was no deeper and more abstract idea of equality, such as equal respect, behind Locke's use of the term. In fact, Locke could have presented the propositional content of his political theory without mentioning natural equality at all. He could have merely stated that due to their God-imposed duty 
to preserve themselves and others, human beings in a state of nature have a right to use other creatures for their survival and to own property. Everyone has a right to observe the law of preservation independently of others, no one has legislative power over another, and all are entitled to punish violations of natural law. The reason why Locke used the notion of natural equality to denote such absence of natural political power relations and the moral facts related to it was that in seventeenth-century Europe this was the conventional thing to do. 201

1 I would like to thank Sami-Juhani Savonius Wroth for commenting on an earlier version of this essay.

2 On Locke as a natural law theorist, see Knud Haakonssen, Natural Law and M oral Philosophy: From Grotius to the Scottish Enlightenment (Cambridge: Cambridge University Press, 1996), 51-8. For recent case studies exploring the natural law background of Locke's views on toleration, see Timothy Stanton, 'Natural Law, Nonconformity, and Toleration: Two Stages on Locke's Way', in John Parkin and Timothy Stanton, eds, Natural Law and Toleration in the Early Enlightenment (Oxford: Oxford University Press, 2013), 35-58, and Ian Harris, 'John Locke and Natural Law: Free Worship and Toleration', in ibid., 59-106.

3 Jeremy Waldron, God, Locke, and Equality: Christian Foundations in Locke's Political Thought (Cambridge: Cambridge University Press, 2002).

4 On these themes, see Timothy Stanton, 'Christian Foundations; or Some Loose Stones? Toleration and the Philosophy of Locke's Politics', Critical Review of International Social and Political Philosophy, 14:3 (June 2011), 323-47. My essay is indebted to Stanton's insightful analysis, though my account of Locke's natural equality slightly departs from his formulations.

5 Waldron follows here Ronald Dworkin's influential account of the character of modern political thought. See Ronald Dworkin, Taking Rights Seriously (London: Duckworth, 1977), 180; Laws' Empire (Cambridge, MA: Harvard University Press, 1986), 296-7. Cf. Alexander Brown, 'An Egalitarian Plateau? Challenging the Importance of Ronald Dworkin's Abstract Egalitarian Rights', Res Publica, 13 (2007), 255-91.

6 Waldron, God, Locke, and Equality, 9-12. 
$7 \mathrm{lbid}$., 1-10. It is worth noting that Dworkin associates equal respect and concern with the question of how the state should treat its citizens, whereas in Waldron's reading of Locke equal respect has to do with universal moral norms which govern human relations even in the state of nature.

8 Jeremy Waldron, 'Basic Equality', New York University Public Law and Legal Theory Working Papers, Paper 107 (2008), 43; at http://lsr.nellco.org/nyu_plltwp/107.

9 Waldron, God, Locke, and Equality, 75-81.

10 In Two Treatises II.69-70 Locke remarks that adult children owe honour and respect towards their parents and explains how we 'may owe honour and respect to an ancient, or wise M an'. John Locke, Two Treatises of Government, ed. Peter Laslett (Cambridge: Cambridge University Press, 1988), 313-14. He never expresses the idea that we would owe respect to others due to some characteristic shared by all human beings. In Some Thoughts concerning Education §117, Locke mentions respect as component of civility which enables a gentleman to maintain good relations with 'inferiours, and the meaner sort of People, particularly Servants'. Young gentlemen should be taught that if they avoid treating servants with 'Domineering Words, Names of Contempt, and an imperious Carriage; as if they were another Race, and Species beneath them', no 'part of their Superiority will be hereby lost, but the Distinction increased, and their Authority strengthened, when Love in Inferiors is join'd to outward Respect, and an Esteem of the Person has a Share in their Submission'. John Locke, Some Thoughts concerning Education, ed. John W. and Jean S. Yolton (Oxford: Oxford University Press, 1989), 182.

11 Waldron, God, Locke, and Equality, 6, 109.

12 Two Treatises II.54, 304. 203

13 The jural character of Locke's natural equality is observed in John Dunn, The Political Thought of John Locke: An Historical Account of the Argument of the 'Two Treatises of Government' (Cambridge: Cambridge University Press, 1969), 121. It is also emphasised in John Marshall, John Locke: Resistance, Religion and Responsibility (Cambridge: Cambridge University Press, 1994), 298-9.

14 Digest I.I.4, Digest 50.17.32.

15 For a short summary of the intellectual history of natural equality prior to Thomas Hobbes, see Kinch Hoekstra, 'Hobbesian Equality', in S. A. Lloyd, ed., Hobbes Today: Insights for the 21st Century (Cambridge: Cambridge University Press, 2013), 94-9.

16 See Harro Höpfl, Jesuit Political Thought: The Society of Jesus and the State, c. 1540-1630 (Cambridge: Cambridge University Press, 2004), 204-62. 
17 John Lilburne, 'The Free-man's Freedom Vindicated', in Andrew Sharp, ed., The English Levellers (Cambridge: Cambridge University Press, 1998), 31; Richard Overton, 'An Arrow Against All Tyrants and Tyranny', in ibid., 55.

18 The most elaborated analysis of Hobbes and equality is now Hoekstra, 'Hobbesian Equality'.

19 Thomas Hobbes, Leviathan, ed. Richard Tuck (Cambridge: Cambridge University Press, 1991), 107.

20 Samuel Pufendorf, De jure naturae et gentium III.ii.1. The English translation is from The Political Writings of Samuel Pufendorf, ed. Graig L. Carr, trans. Michael Seidler (Oxford: Oxford University Press, 1994), 159.

21 See Kari Saastamoinen, 'Pufendorf on Natural Equality, Human Dignity, and Self-Esteem', Journal of the History of Ideas, 71:1 (2010), 39-62.

22 John Locke, Political Essays, ed. M ark Goldie (Cambridge: Cambridge University Press, 1997), 69 71.

23 Ibid., 135-6.

24 Some Thoughts concerning Education, §186, 239.

25 See Haakonssen, Natural Law and M oral Philosophy, 52-5.

26 Two Treatises, II.6, 271, II.16, 278-9, II.135, 358.

27 For an insightful, if somewhat extreme formulation of this point, see Knud Haakonssen, 'Natural Law and Personhood: Samuel Pufendorf on Social Explanation', Max Weber Lecture, European University Institution, 2010; at http://hdl.handle.net/1814/14934.

28 Robert Filmer, 'Patriacha' and other Political Writings, ed. Johann P. Sommerville (Cambridge: Cambridge University Press, 1991), 2-3. On the character of Filmer's argument, see lan Harris, 'Robert Filmer', in S.-J. Savonius-Wroth, Paul Schurman and Jonathan Walmsley, eds, The Bloomsbury Companion to Locke (London: Bloomsbury, 2014), 57-61. Cf. Cesare Cuttica, Sir Robert Filmer (1588-1653) and the Patriotic Monarch: Patriarchalism in Seventeenth-Century Political Thought (M anchester: M anchester University Press, 2012).

29 Filmer, 'Patriacha' and other Political Writings, 19-21.

30 lbid., 12.

31 Two Treatises II.3, 268.

32 Ibid., II.135, 357-8.

33 Ibid., I.67, 190.

34 Ibid., Il.4, 269. 
35 Ibid., II.6, 270-1.

36 Ibid., Il.4, 269.

37 Ibid., II.2-3, 268.

38 Ibid., II.7, 272. In God, Locke, and Equality, 137, Waldron points out how in paragraph II.123, 350, Locke describes a person living in the state of nature as an 'absolute Lord of his own Person and Possessions, equal to the greatest, and subject to no Body'. In so far as Locke speaks here about an absolute lord, this is of course an overstatement, as human beings are all God's property. The status of a worldly lord is, for Locke, a legal construction which in no way liberates its holder from whatever moral obligations he or she has towards others as a human being. Thus, to be a lord of one's own person and possessions means nothing more than not to be under anyone's legislative power.

39 lbid., Il.54, 304.

40 lbid., Il.14-15, 276-8.

41 lbid., Il.2, 269.

42 For Waldron's use of the Essay, see God, Locke, and Equality, 49-81.

43 Stanton, 'Christian Foundations', 325, 340.

44 John Locke, An Essay concerning Human Understanding, ed. Peter H. Nidditch (Oxford: Oxford University Press, 1975), III.ix.3, 476.

45 Ibid., II.xxvii.8, 335.

46 Two Treatises II.58, 306.

47 Stanton, 'Christian Foundations', 338.

48 See George Windstrup, 'Locke on Suicide', Political Theory, 9:2 (M ay 1980), 169-82.

49 An Essay concerning Human Understanding, III.xi.16, 517.

50 Political Essays, 267-8.

51 Two Treatises I.86, 204-5.

52 Ibid., II.61, 308-9.

53 Ibid., Il.58, 306.

54 Ibid., II.63, 309.

55 Ibid., Il.4, 269.

56 Ibid., II.6, 271.

57 Ibid., II.6, 271, II.17, 279.

58 Ibid., Il.11, 274.

59 Stanton, 'Christian Foundations', 336. 
60 Two Treatises II.8, 272.

61 Ibid., Il.128, 352.

62 Haakonssen, Natural Law and M oral Philosophy, 55-6.

63 Two Treatises II.54, 304.

64 On reading Locke's views on ownership in terms of imperfect duties, see Robert Lamb, 'Locke on Ownership, Imperfect Duties and "the Art of Governing"', The British Journal of Politics and International Relations, 12 (2010), 126-44.

65 See Pufendorf, De jure, I.i.19; The Political Writings of Samuel Pufendorf, 19.

66 Two Treatises II.12, 275.

67 An Essay concerning Human Understanding, II.xxviii.12, 356-7.

68 Marshall, John Locke, 299, 159-63.

69 Two Treatises II.70, 314.

70 lbid., Il.66, 311.

71 lbid., Il.67, 312.

72 lbid., Il.68, 313.

73 John Locke, A Letter concerning Toleration and Other Writings, ed. Mark Goldie (Indianapolis: Liberty Fund, 2010), 25.

74 Locke admits that the right of the father to decide his inheritors establishes, among the landed classes, a form of authority which can be said to be sanctioned by punishments. He is worried that since this practice mainly takes place in the context of the family, 'it passes in the World for a part of Paternal Jurisdiction', and could be seen as supporting Filmer's doctrine of paternal power. It is, therefore, important for Locke to emphasise that this practice is not a part of parental power, but a separate right, common to all human beings, 'to bestow their Estates on those who please them best'. Two Treatises, II.72, 314-5.

75 Two Treatises, II.82, 312.

76 Ibid., I.47, 174.

77 Ibid., II.142, 363. Locke's expression 'one Rule for Rich and Poor' may suggest that he has only different social positions in mind and doesn't want to say anything about gender.

78 For different assessments on marital power, most of them made from the perspective of modern liberalism, see Nancy J. Hirschmann and Kristie M. McClure, eds, Feminist Interpretations of John Locke (University Park: Pennsylvania State University Press, 2007).

79 Two Treatises II.94, 329. 
80 Ibid., II.142, 363.

81 Ibid., I.129, 236. 208 